\title{
IMMUNOMODULATORY EFFECT OF A MIXTURE OF WATER EXTRACTS OF BETEL (PIPER BETLE L.) LEAF AND (UNCARIA GAMBIR ROXB.) GAMBIER ON PHAGOCYTIC CELLS AND MODULATION ON PHOSPHATASE ENZYME OF MICE
}

\author{
MUHAMMAD YANIS MUSDJA ${ }^{1 *}$, AMINAH NURHADIYAH ${ }^{1}$, ZILHALDIA $^{1}$, ANDRIA AGUSTA $^{2}$ \\ ${ }^{1}$ Department of Pharmacy, State Islamic University, Syarif Hidayatullah, Jakarta, Indonesia. ${ }^{2}$ Department of Microbiology, Indonesian \\ Institute of Sciences, Cibinong, Bogor, Indonesia. *Email: yanis.musdja@uinjkt.ac.id
}

Received: 27 August 2019, Revised and Accepted: 08 October 2019

ABSTRACT

Objective: This study was to determine the immunomodulatory effect of a mixture of water extracts of betel (Piper betle L.) leaf and (Uncaria gambir Roxb.) gambier on phagocytic cells and modulation on phosphatase enzyme of mice.

Methods: Mixture of extracts of betel leaf and gambier (ratio, 429:71) was given to seven groups of mice for 14 days with doses of 100, 200, and $400 \mathrm{mg} / \mathrm{kg}$ body weight (BW). Two kinds of immunomodulatory drug in syrup form commonly used in the treatment of infectious were used as positive controls. The peritoneal fluid of mice containing macrophage cells was isolated by performing surgery. Immunomodulatory effect was done by calculating the number of phagocytosis activity and capacity of macrophage cells of mice, and measurement of phosphatase enzyme was done using a spectrophotometer ultraviolet visible on $\lambda=405 \mathrm{~nm}$, after $1 \mathrm{~h}$ intraperitoneal injection Staphylococcus epidermidis on each group of mice. Immunomodulatory effects of each group of a mixture of extract were compared with negative control, normal control, and positive controls.

Results: The result showed that doses administered $200 \mathrm{mg} / \mathrm{kg}$ BW of mixture extract most efficacy for both phagocytosis activity and phagocytosis capacity as well as for the results of testing for phosphatase enzyme. Based on statistical tests, it was significantly different ( $\mathrm{p} \leq 0.05$ ), if compared with negative controls and normal controls but not significantly different, if compared to positive controls $(\mathrm{p} \geq 0.05)$.

Conclusion: Based on the results of this study, it has been obtained that a mixture of water extracts of betel (P. betle L.) leaf and (U. gambir Roxb.) gambier with a dose of $200 \mathrm{mg} / \mathrm{kg} \mathrm{BW}$ is very potential to be used as an immunomodulatory.

Keywords: Betel leaf, Immunomodulatory, Phagocytic macrophage, Gambier, Phosphatase enzyme.

(c) 2019 The Authors. Published by Innovare Academic Sciences Pvt Ltd. This is an open access article under the CC BY license (http://creativecommons. org/licenses/by/4. 0/) DOI: http://dx.doi.org/10.22159/ajpcr.2019.v12i11.35496

\section{INTRODUCTION}

Betel chewing is the number two biggest addiction in the world after smoking. This is mostly done by people living in the South Asian region, Southeast Asia, China, Pacific Islands, and several other countries in the world. The people who betel chewing will cause addiction because betel chewing can cause feelings of comfort (Euphoria) and eliminate headaches [1-3].

Betel chewing has advantages and disadvantages. The advantages of this are to prevent infectious diseases, prevent worm disease, increase immune system (immunomodulatory), eliminate bad breath, prevent toothache, cleanse the mouth and teeth, strengthen teeth, improve appetite, improve digestion, eliminate headaches, treat joint pain, prevent diabetes, eliminate constipation, cure inflammation, wound healing, as an aphrodisiac, and others [2-5]. The disadvantage of betel chewing is that it can cause oral cancer, this happens when people who betel chewing add young areca fruit. Because young areca fruit contains alkaloids; arecoline, guvacoline, guvacine, and arecaidine, where these alkaloids in the body can form derivatives of nitrosamine compounds that are carcinogenic $[1,3,6,7]$.

On the other hand, based on research of Ramya and Anuradha (2015), on 25 betel chewers, male patients (aging $\geq 45$ years) compared to non-chewers when chewing betel added with tobacco, obtained an increase in the level of plasma glucose, serum enzymes such as alanine aminotransferase, aminotransferase, alkaline phosphatase, aspartate, creatinine cholesterol, high-density lipoprotein, serum cholesterol, and triglycerides urea and the protein level were decreased [7] so that the disadvantage of betel chewing can be avoided, in this study, we did not use young areca fruit and tobacco. Therefore, this research was to find solutions to people who betel chewing, where they get the advantage to their health and avoid disadvantage to their health.

The number of people who betel chewing the biggest in the world is in India. It was estimated that around 170-440 million Indian residents and in the world around 550-700 million are betel chewing; therefore, there are several terms for betel chewing in India, namely, pan masala (young areca fruit, slaked lime, gambier, and other mixtures), gutka (pan masala plus tobacco), mainpuri (tobacco, young areca fruit, slaked lime, camphor, and cloves), mawa (young areca fruit, tobacco, and slaked lime), and a mixture of tobacco with slaked lime called khaini $[3,10]$.

Research in India conducted at Tata Memorial Hospital showed that $28-30 \%$ had been diagnosed with oral submucous fibrosis due to betel chewing more than 12 times a day [7].

As we know, infectious diseases are still a major problem in the health sector in the world, with the increasing number of resistant antibiotics from time to time, so for the next few years, the morbidity and mortality rate of the world population due to infectious diseases will increase sharply, to prevent the increase of infectious diseases, it is necessary to prevent this problem. Therefore, the role of immunomodulatory drugs will be increasingly important [10].

Actually, the body has a special system to eradicate various infectious and toxic substances. Immune system cells work together with an organized division of labor to deal with various threats to the body. This system consists of blood leukocytes and tissue cells derived from 
leukocytes. Immune system cells work together in two ways to counter various threats to the body, namely, through the process of phagocytosis and forming antibodies. Both of these systems can work individually or work together. However, the body's immune system, both specific and non-specific, or the system of cooperation between the body's immune system can decrease; therefore, immunomodulatory drugs are needed $[11,12]$.

Immunomodulators are both natural and synthetic substances that can help regulate the immune system balance. Immunomodulators work to affect or maintain the body's defense system. If a person has an immune system deficiency, immunomodulators will work by stimulating (immunostimulatory) the body's immune system, whereas in people with excessive immune reactions, immunomodulators work by suppressing or normalizing (immunosuppressants) the body's immune system, therefore, immunomodulators work to optimize the body's defenses so that it indirectly has overcome or reduced various pathological conditions or other health problems due to not optimal body defense systems including infectious diseases, allergies, cancer, benign, or malignant neoplasms $[11,12]$.

Immunomodulatory class drugs work in 3 ways, namely, through: $[13,14]$

1. Immunorestoration is an effort to improve the immune system which is disrupted by giving the immune system components, for example, giving immunoglobulins, blood plasma, bone marrow transplants, and others.

2. Immunostimulation is an effort to improve the compromised immune system by stimulating the immune system, for example, by administering hormone extracts from the thymus gland, lymphokines, interferon, levamisole, methisoprinol, muramyl dipeptide, and others.

3. Immunosuppression is an effort to suppress the immune response, such as steroid administration. This is often applied to people who experience organ transplants coming from other people to overcome rejection reactions from the body.

Synthetic immunomodulatory drugs besides expensive also have many side effects. While immunomodulatory drugs from natural products, such as Echinacea purpurea, Phyllanthus niruri, and Maitake mushroom (Grifola frondosa) are more suitable to prevent upper tract infections and certain diseases. Therefore, it is hoped that the discovery of immunomodultar drugs from natural products with different effects of pharmacology with E. purpurea, $P$ niruri, $G$. frondosa, etc. $[10,11,13]$.

On the other hand, the phosphatase enzyme is playing a role in increasing the performance of the activity and phagocytic capacity of macrophage cells; therefore, to determine the work activity of the immunomodulatory compound, it is necessary to determine the level of the enzyme phosphatase due to the work activity of the immunomodulatory compound $[15,16]$.

\section{MATERIALS AND METHODS}

Materials

Betel leaf was obtained from Research Institute for Spices and Medicinal Plants (Balitro), Bogor. While gambier was obtained from Payakumbuh (West Sumatra), the largest gambier-producing region in the world, determination of plant authentication was carried out in Biology Research Center, Indonesian Institute of Sciences, Bogor, Indonesia.

Preparation of a mixture of betel leaf extract and gambier powder Betel leaf and gambier were made into powder, then $429 \mathrm{~g}$ of betel leaf powder and $71 \mathrm{~g}$ of gambier powder were added with water up to volume $1 \mathrm{~L}$, stirred in a blender; then, the mixture was filtered with Whatman paper No. IV and dried with a freeze dryer and calculated the yield was obtained [18].

\section{Preparation of experimental animals}

Swiss albino mice (weight ranges from 25 to $30 \mathrm{~g}$ ) were obtained from Faculty of Veterinary Medicine, Bogor Agricultural Institute. The mice were acclimatized for 9 days and maintained on $12 \mathrm{~h}$ light, $12 \mathrm{~h}$ dark cycle on temperature $25^{\circ} \mathrm{C}$. The mice were given standard diet and water ad libitum and kept under standard conditions in animal house based on norms of Committee for the Purpose of Control and Supervision on Experiments on Animals (CPCSEA, 2003) [19].

\section{Administration of test preparation on experimental animals}

Administration of test preparation on experimental animals is shown in Table $1[18,19]$

\section{Preparation of bacterial suspension}

Staphylococcus epidermidis was obtained from Microbiology Laboratory, Cipto Mangunkusumo Hospital, Jakarta. The stock of these bacteria was kept in nutrient agar and then inoculated into the broth medium, incubation at shaker incubator with speed $120 \mathrm{rpm}$, temperature 30 ?, for $24 \mathrm{~h}$ until reach the active phase. Adjust the amount of bacteria using spectrophotometer ultraviolet (UV) visible $\pm 109 \mathrm{cfu} / \mathrm{ml}(\mathrm{T}=25 \%$, $\lambda=580 \mathrm{~nm})[18,20,21]$.

\section{Administration of test preparation on experimental animals} Administration of test preparations to experimental animals was based on the dosage written in Table 1.

Administration of test preparations was done once daily as long as 2 weeks. On the $15^{\text {th }}$ day, $0.5 \mathrm{ml}\left(10^{9} \mathrm{cfu} / \mathrm{sml}\right)$ was injected intraperitoneally, $1 \mathrm{~h}$ after $S$. epidermidis was injected, experimental animals was dissected on his stomach and into the peritoneal cavity was injected $1 \mathrm{ml}$ of buffered phosphate saline solution and the peritoneal fluid was taken to be used in calculating the activity and capacity of phagocytosis of mice $[18,20,21]$.

Preparation of glass slides for analysis activity and capacity of phagocytosis

Take $100 \mu$ peritoneal liquid and place it on a glass object and fix it with absolute methanol for $5 \mathrm{~min}$, then do the staining with Giemsa $4 \%$, after $45 \mathrm{~min}$ dip it in $0.1 \mathrm{M}$ acetic acid and wash with distilled water, then dry and observe under a light microscope [18,20,21].

Determination of macrophage phagocytosis activity and capacity Determination of value phagocytosis activity of macrophages was conducted with calculate the amount of macrophages that carried out phagocytosis activity of 100 macrophages against a number of $S$. epidermidis. Phagocytosis activities calculation was performed 3 times from different slides for one experimental animal.

Determination of value phagocytosis capacity of macrophages was conducted with calculate the amount 50 of macrophages that still active carried out phagocytosis against a number $S$. epidermidis, the selection of macrophages was conducted as randomly. Phagocytosis capacities calculation was performed 3 times from different slides for one experimental animal $[18,20,21]$.

Table 1: Administration of test preparation on experimental animals

\begin{tabular}{|c|c|c|}
\hline Group & Name of group & Doses \\
\hline 1 & $\begin{array}{l}\text { Small dose test } \\
\text { preparation }\end{array}$ & $100 \mathrm{mg} / \mathrm{kg} \mathrm{BW}$ \\
\hline 2 & $\begin{array}{l}\text { Medium dose } \\
\text { test preparation }\end{array}$ & $200 \mathrm{mg} / \mathrm{kg} \mathrm{BW}$ \\
\hline 3 & $\begin{array}{l}\text { Large dose test } \\
\text { preparation }\end{array}$ & $400 \mathrm{mg} / \mathrm{kg} \mathrm{BW}$ \\
\hline 4 & Normal control & Water \\
\hline 5 & Negative control & CMC $0.5 \%$ \\
\hline 6 & Positive control 1 & $\begin{array}{l}\text { Echinacea syrup was given } \\
154.3 \mathrm{mg} / \mathrm{kg} \mathrm{BW}\end{array}$ \\
\hline 7 & Positive control 2 & $\begin{array}{l}\text { Phyllanthus niruri syrup } \\
\text { was given } 154.3 \mathrm{mg} / \mathrm{kg} \mathrm{BW}\end{array}$ \\
\hline
\end{tabular}

Positive control 1 is Echinacea syrup. Positive control 2 is Phyllanthus niruri syrup. Both of these positive controls are immunomodulatory drugs purchased from the drug store. BW: Body weight 


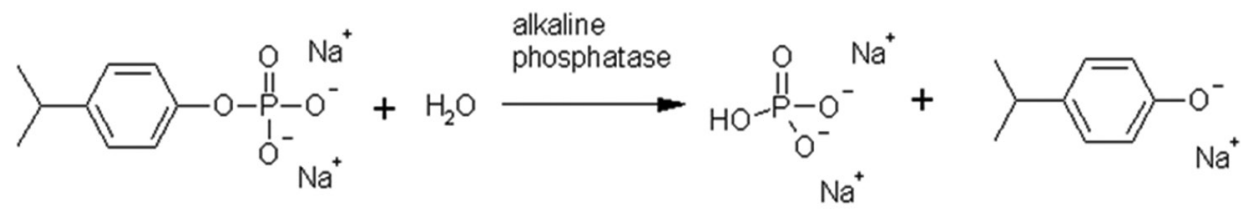

4-nitrophenylphosphate

\author{
4-nitrophenolate \\ $\lambda_{\max }=405 \mathrm{~nm}$ \\ yellow color
}

Fig. 1: The reaction process of 4-nitrophenyl phosphate (colorless) and $\mathrm{H}_{2} \mathrm{O}$ in the presence of alkaline phosphatase forms Na phosphate and 4-nitrophenolate (yellow color) and absorbs strongly at $405 \mathrm{~nm}$

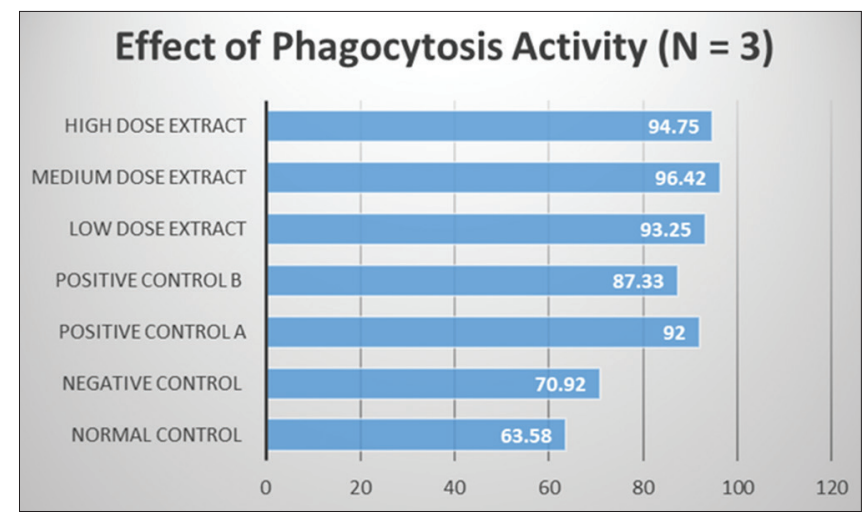

Fig. 2: Effect phagocytosis activity of mixture of betel and gambier to macrophage cell of mice

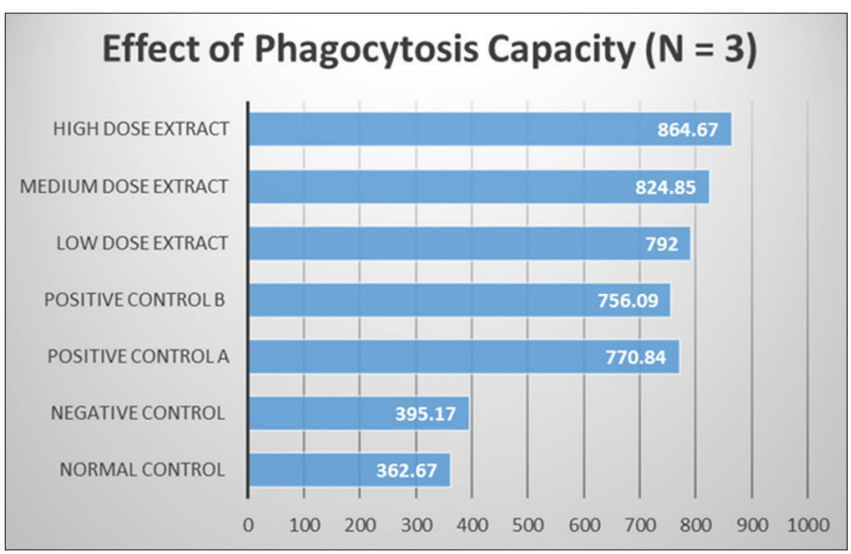

Fig. 3: Effect phagocytosis capacity of a mixture of betel and gambier to macrophage cell of mice

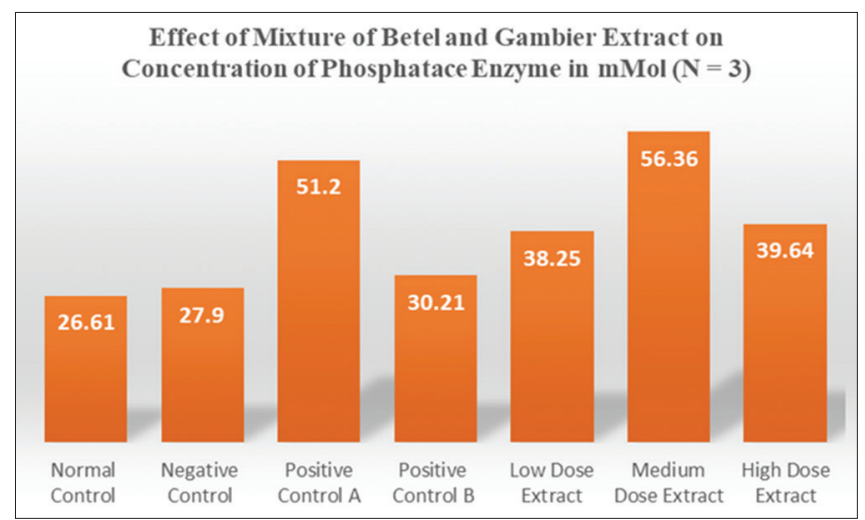

Fig. 4: The effect of a mixture of betel and gambier extracts on the concentration of the phosphatase enzyme

\section{Measurement of the acid phosphatase enzyme}

On the measurement of the acid phosphatase enzyme, as a standard solution was used a 4-nitrophenolate solution, measurement of the acid phosphatase enzyme level was done using a spectrophotometer UV visible on $\lambda=405 \mathrm{~nm}$ [20-22]. The reaction process that occurs is shown in Fig. 1 [22-23].

\section{RESULTS AND DISCUSSION}

The results of the authentication for plants taxonomy that was done by Herbarium Bogoriense, Biological Research Center, Indonesian Institute of Sciences, indicating that the plant used for this research were Piper betle Linn. and Uncaria gambir Roxb.

The yield of betel chewing extract that was made with ratio betel and gambier (421:71) was obtained $9.92 \%$ dry extract. Determination of this ratio was based on the habits of people who eat chewing betel.

As shown in Fig. 2, for phagocytosis activity, the results of statistical tests showed a significant difference $(p<0.05)$ between the increase in phagocytic activity by a mixture of betel and gambier extracts as well as positive control A and positive control B compared to normal control and negative control, whereas for low-dose and high-dose test preparations, there was no significant difference $(p>0.05)$ in positive control A and positive control B. However, the medium dose test preparation was significantly different from positive control A ( $p<0.05)$.

As shown in Fig. 3, for phagocytosis capacity, the results of statistical tests showed a significant difference $(\mathrm{p}<0.05)$ between the increase in phagocytic activity by a mixture of betel and gambier extracts as well as positive control A and positive control B compared to normal control and negative control, whereas for low-dose and medium-dose test preparations, there was no significant difference ( $p>0.05$ ) in positive control A and positive control B. However, the high-dose test preparation was significantly different from positive control 1 and positive control $2(\mathrm{p}<0.05)$.

As shown in Fig. 4, for the effect of the test preparation on the concentration of the phosphatase enzyme, the results of statistical tests showed a significant difference $(p<0.05)$ between mixtures of betel and gambier extracts as well as positive control A compared to normal control and negative control and positive control B was no significant difference $(p>0.05)$ compared to normal control and negative control, whereas for low-dose and medium-dose test preparations, there was no significant difference $(\mathrm{p}>0.05)$ in positive control A. However, the highdose test preparation was significantly different from positive control A and positive control B $(\mathrm{p}<0.05)$.

According to Domingues et al. (2011), chemical compounds of gambier work to trigger an immunomodulation toward a Th2 cytokine profile, in this study, also were occurred at doses of $125 \mathrm{mg} / \mathrm{kg}$ body weight (BW) work as stimulant and at a dose of $500 \mathrm{mg}$ work as immunosuppression [24].

On the other hand, according to Labro (2000) in this condition, large doses will cause interference with the immune system or certain damage to macrophage cells because there is a working relationship between 
macrophage cells not only used as bacterial phagocytosis and foreign objects in the body but macrophage cells also release several chemical mediators to interact with each other between the immune system in the body, the mechanism of the immune system is disrupted, causing phagocytic activity and capacity to be disrupted. However, if the dosage is appropriate, macrophage cells will work together with other parts of the body's antibody system to optimize the activity and capacity of phagocytosis. From the system, means that in this case at a dose of $200 \mathrm{mg} / \mathrm{kg}$ BW, the activity and capacity of macrophage cells have reached optimal conditions [12].

As is known, that betel and gambier have antibacterial activity. Betel leaf has been known as an antibacterial against several pathogenic bacteria, namely, Candida albicans, Diplococcus pneumoniae, Proteus mirabilis, Proteus vulgaris, Klebsiella aerogenes, Salmonella typhimurium, Shigella flexneri, Staphylococcus aureus, Streptococcus mutans, Staphylococcus faecalis, and Vibrio cholerae [26,27].

Gambier has been known to work as an antibacterial against pathogenic bacteria, namely, Escherichia coli, Bacillus subtilis, Proteus aeruginosa, $S$. flexneri, S. aureus, S. epidermidis, P. vulgaris, and P. mirabilis [24,25].

Increasing the concentration of phosphatase enzymes was higher in the extract mixture of betel and gambier than in positive control 1 containing Echinacea and positive control 2 containing $P$. niruri, in this case it is in accordance with Labro opinion, that plants that work as immunomodulators and antibacterials are better at preventing bacterial growth and immunomodulators than plants that only work as immunomodulators and plants that only work as antibacterials, because of the work of synergies between immunomodultor compounds with antibacterial compounds [12].

\section{CONCLUSION}

The results of this study indicate that a mixture water extracts of betel leaf and gambier have excellent immunomodulatory effects in increasing the work of antibodies in the body of mice. In this case, the medium doses (200 mg/kg BW) have the best effect compared to low doses (100 mg/kg BW) and high doses (400 mg/kg BW).

\section{ACKNOWLEDGMENT}

The authors would like to thank staffs of Biological Research Center, Indonesian Institute of Sciences, Cibinong, Bogor, for their assistance in carrying out this research.

\section{AUTHORS' CONTRIBUTIONS}

This manuscript was done in collaboration among all authors. The MYM author designed this study, supervised the work, and edited the final version of the manuscript. The AN author manages experimental analysis of this study and wrote the first draft of the manuscript. $\mathrm{Z}$ author did part of the experiment. The AA author codesigned the research and carried out statistical analysis did part. All authors read and agreed to the final of this manuscript.

\section{CONFLICTS OF INTEREST}

The authors declare no conflicts of interest and this study did not involve any financial support from other agencies.

\section{REFERENCES}

1. Hossain MF, Anwar M, Akhtar S, Numan SM. Uses impact of betel leaf (Piper betle L.) on public health. Sci J Public Health 2017;5:408-10.

2. Atwal GS, Warnakulasuriya KA, Gelbier S. Betel-quid chewing habits among a sample of South. Asians J Dent Res 1996;75:115-7.

3. Rooban T, Mishra G, Elizabeth J, Ranganathan K, Saraswathi TR. Effect of habitual arecanut chewing on resting whole mouth salivary flow rate and pH. Indian J Med Sci 2006;60:95-105.

4. Ataguba GA, Dong HT, Rattanarojpong T, Senapin S, Salin KR. Piper betle leaf extract inhibits multiple aquatic bacterial pathogens and in vivo Streptococcus agalactiae infection in Nile Tilapia. Turk J Fish Aquat Sci 2018;18:671-80.
5. Budiman A, Khoerunnisa R, Qoriah T. Wound-healing test of piper betle leaf extract and Aloe vera in gel preparation. Int J Appl Pharm 2018;10:86-91.

6. Bascones-Martinez A, Mattila R, Gomez-Font R, Meurman JH. Immunomodulatory drugs: Oral and systemic adverse effects. Med Oral Patol Oral Cir Bucal 2014;19:e24-31.

7. Nair U, Bartsch H, Nair J. Alert for an epidemic of oral cancer due to use of the betel quid substitutes gutkha and pan masala: A review of agents and causative mechanisms. Mutagenesis 2004;19:251-62.

8. Ramya M, Anuradha R. Biochemical changes in betel quid chewers and non-chewers of kakkarai. Asian J Pharm Clin Res 2015;8:122-4.

9. Mohanto S, Datta S and Mandal S, Piper Betel Linn: A brief studyInternational Journal of Current Medical And Pharmaceutical Research, Vol. 3, Issue, 02, 1290-1296, February, 2017

10. World Health Organization. World Health Statistics. Monitoring Health for the SDGs, Sustainable Development Goals. Geneva: World Health Organization; 2018.

11. Kumar N, Misra P, Dube A, Bhattacharya S, Dikshit M, Ranade S. Piper betle Linn. A maligned pan-asiatic plant with an array of pharmacological activities and prospects for drug discovery. Curr Sci 2010;99:922-31.

12. Labro MT. Interference of antibacterial agents with phagocyte functions. Clin Micr Rev 2000;3:619-28.

13. Venkatalakshmi P, Vadivel V, Brindha P. Role of phytochemicals as immunomodulatory agents: A review. Int J Green Pharm 2016;10:2.

14. Kayser O, Masihi KN, Kiderlen AF. Natural products and synthetic compounds as immunomodulators. Expert Rev Anti Infect Ther 2003;1:319-35.

15. Barford D, Das AK, Egloff MP. The structure and mechanism of protein phosphatases: Insights into catalysis and regulation. Annu Rev Biophys Biomol Struct 1998;27:133-64.

16. Bull H, Murray PG, Thomas D, Fraser AM, Nelson PN. Acid phosphatases. Mol Pathol 2002;55:65-72.

17. Snipes RG, Lam KW, Dodd RC, Gray TK, Cohen MS. Acid Phosphatase Activity in Mononuclear Phagocytes and the U937 Cell Line: Monocyte-Derived Macrophages Express Tartrate-Resistant Acid Phosphatase. Available from: http://www.bloodjournal.org by guest on. [Last accessed on 2017 Apr 11].

18. Musdja MY, Syarif A, Poerwaningsih EH, Agusta A. Modulation of Macrophage Immune Responses of Extract Mixture of Betel Leaf (Piper Betle, L), Gambier (Uncaria Gambier, Roxb) and Calcium Hydroxide on Phagocytic Cells of Mice, $1^{\text {st }}$ ed. Proceeding of The $2^{\text {nd }}$ International Conference on Pharmacy and Advanced Pharmaceutical Sciences, Book I: Pharmaceutical Science; 2011. p. 76-81.

19. Committee for the Purpose of Control and Supervision on Experiments on Animals (CPCSEA). CPCSEA guidelines for laboratory animal facility. Indian J Pharmacol 2003;35:257-74.

20. Kusmardi, Shirly K, Enif ET. Immunomodulatory effects of Cassia alata Linn leaf extract on the activity and capacity of phagocytosis of macrophages. Facu Med Univ Indonesia Jakarta J Makara 2007;2:50-5.

21. Dey PM. Method in Plant Biochemistry Assay for Bioactivity. Vol. 6. K. Harbone Boston, Sydney, Toronto: Hostechman, Academic Press; 1991. p. 196-8.

22. Kiefer HC. Measurement of phosphatases in biological fluids. Ann Clin Lab Sci 1977;7:500-5.

23. Sridhar K, Narayanan M, Goswami K. Measurement of total alkaline phosphatase activity in human serum using charcoal activated paranitro phenyl phosphate. Int J Sci Res 2016;5:1315-7.

24. Domingues A, Sartori A, Valente LM, Golim MA, Siani AC, Viero RM, et al. Uncaria tomentosa aqueous-ethanol extract triggers an immunomodulation toward a th2 cytokine profile. Phytother Res 2011;25:1229-35.

25. Musdja MY, Hapsaria MA, Agusta A. Comparison of activity and inhibitory mechanism between $(+)$-catechin and water extract of gambier (Uncaria gambir Roxb.) against some bacteria. Sci J PPIUKM, 2017;4:55-60.

26. Musdja MY, Syarif A, Poerwaningsih EH, Agusta A. Comparison Between Activity and Mechanism of Inhibition of Essential Oil Betel Leaf (Piper Betle, Linn) With Eugenol Against Some of Bacterial Pathogens, The 4il International Seminar of Indonesia Society for Microbiologt and IUMS-ISM Outreach Program on Food Safely 'Indonesian Microbial Resources: Diversity and Global Impact' BaliIndonesia I 22-24,h; 2011. p. 90-9.

27. Shitut S, Pandit V, Mehta BK. The antimicrobial efficiency of Piper betle Linn leaf (stalk) against human pathogenic bacteria and 
phytopathogenic fungi. Cent Eur J Public Health 1999;7:137-9. 